Steemann Nielsen, E.: On detrimental effects of high light intensities on the photosynthetic mechanism. Physiol. Plant. 5, 334-344 (1952)

Steemann Nielsen, E., Jorgensen, E. G.: The physiological background for using chlorophyll measurements in hydrobiologie and a theory explaining daily variations in chlorophyll concentrations. Arch. Hydrobiol. 58, 349-357 (1962)

Strickland, J. D. H., Parsons, T. R.: A practical handbook of seawater analysis. Bull. Fish. Res. Bd. Can., No. 167, 311 p. (1968)

Verduin, J.: A table of photosynthetic rates under optimal near-natural conditions. Amer. J. Bot. 40, 675-679 (1953)

Yentsch, C. S.: Relationship between chlorophyll and photosynthetic carbon production with reference to the measurement of decomposition products of chloroplastic pigments, p. 323-346. In: C. R. Goldman, ed., Primary productivity in aquatic environments. Mem. Ist. Ital. Idrobiol. Suppl. 18. Berkeley, Calif.: Univ. of Calif. Press 1969

Dr. Joyce M. Foster

Department of Zoology

Arizona State University

Tempe, Arizona 85281, USA

\title{
Erratum
}

\section{Quantitative Analysis of the Functional Relationships Existing between Ecosystem Components}

\author{
I. Analysis of the Linear Intercomponent Mass Transfers \\ D. F. Smith
}

Oecologia (Berl.) 16, 97-106 (1974)

On page $99 \mathrm{Eq}$. (2) should read:

$$
\begin{gathered}
-f_{i 1} Q_{1}-f_{i 2} Q_{2}-\cdots-f_{i(i-1)} Q_{(i-1)}+\left(s-f_{i i}\right) Q_{i}- \\
f_{i(i+1)} Q_{i+1}-\cdots-f_{i n} Q_{n}=Q_{i}(t=0)
\end{gathered}
$$

